\title{
Motiveren kun je leren?
}

Bespreek je rookgedrag van ouders bij een astmatisch kindje? Begin je bij een patiënt die bij je komt om een moedervlek te laten beoordelen over zijn (over)gewicht? Ga je wekelijks wandelen met je patiënten? Het eerste is voor de meeste artsen vanzelfsprekend, het tweede al minder en het laatste gaat duidelijk verder dan geïndiceerde preventie in de spreekkamer, wat we als een kerntaak beschouwen.

Ik herken me als huisarts in de resultaten van het onderzoek van Scheenhart in dit nummer. Daarin beschrijft ze dat veel huisartsen preventie wel zien als hun taak, maar moeite hebben met het ter sprake brengen bij een hulpvraag die niet gerelateerd is aan leefstijl. Bovendien wordt motivatie van de patiënt als belemmerende factor genoemd. De Vries houdt een pleidooi waarom leefstijlgeneeskunde bij uitstek binnen het domein van de huisarts valt en geeft aan dat het mogelijk is een patiënt binnen 30 seconden effectief door te verwijzen voor een gedragsinterventie. Dit lijkt me nog niet zo gemakkelijk. Het peilen of iemand ambivalent is ten opzichte van gedragsverandering of reeds gemotiveerd is tot handelen, is juist iets wat tijd kost.
Intrinsieke motivatie is niet alleen van belang bij de patiënt, maar ook bij de dokter. Laat u zich in dit nummer inspireren door positieve resultaten van het Keer-Diabetes2-Om-programma en een beweegprogramma bij COPD-patiënten. Bij deze interventies blijft soms wel de vraag hoe lang de gedragsverandering beklijft. En veelal zijn de deelnemers een selecte groep van gemotiveerde patiënten. Hoe krijgen we de rest zo ver? En wat is de rol van motiverende gespreksvoering hierin?

Vooralsnog kan extra tijd voor de patiënt mij hierbij wel helpen. Hoewel de huidige COVID-19-pandemie vooral demotiverend werkt, geven die extra 5 minuten tijdens het spreekuur me net iets meer 'ademruimte' om bijvoorbeeld te vragen naar psychosociale context. Of bij die ene patiënt: toch beginnen over zijn teveel aan gewicht? -

Marian van den Brink, lid redactiecommissie
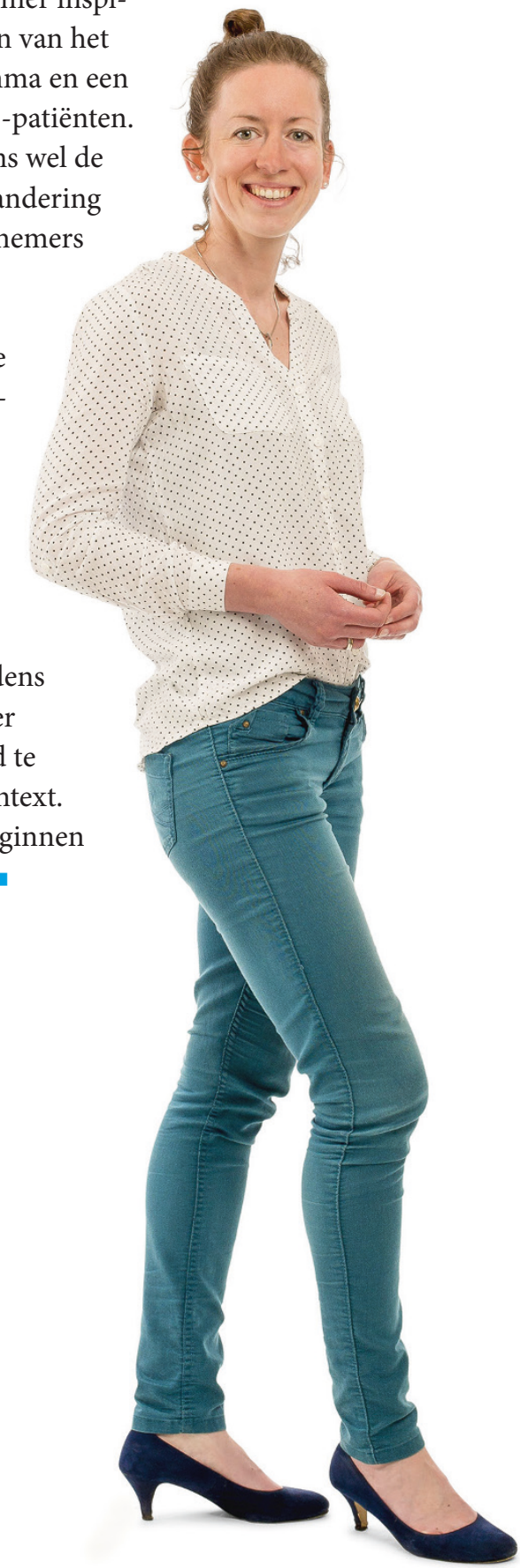